\title{
Quantum Learning Method in Indonesian Language Course
}

\author{
Yunisa Oktavia and Fasaaro Hulu \\ English Department \\ Putera Batam University \\ Batam, Indonesia \\ yunisaoctavia@yahoo.com, fashulu@gmail.com
}

\begin{abstract}
This research wasconducted because it was found the student's learning achievement was still low in Putera Batam University. This is reflected in the students's test results which did not met the required by the university. There are some problems faced by students in learning Indonesian language such as (1) Low reading culture among students (2) Students difficulties in developing ideas into the form of writing systematically, (3) Static method of teaching and lack of parallelism between the material's and the students' need (4) Lack of use of interactive media. The study aims to describe the method of Quantum Learning in the Indonesian language course in Putera Batam University. This research method used descriptive analysis method. The subjects of this research were the students of the English literature study program in the academic year of the 2016/2017 Putera Batam University. Data collection was done through ditributing instruments consisting of observation sheets, field notes and interview forms. The results shows that the Quantum Learning Method had successefully contributed to improving the learning achievement of the second year students' of the English Literature program who studied Indonesian Language as a general course in Putera Batam University
\end{abstract}

\section{Keywords: Quantum Learning Method, Indonesian Language}

\section{INTRODUCTION}

The researcherswere motivated to conducted this research because it was found that the students' learning achievement still low. This finding was reflected in the students' results of the exams where there many students who fail the Indonesian language course. Infact, Indonesian Language was a compulsory subject.This means that it was a must for the students to pass it. Indonesian language courses are considered by the students as an easy course and trivial. However, the reality is not so. Indonesian language courses have a significant level of difficulties because there are still many mistakes made by students who are not in accordance with KBBI and General Guidelines Indonesian Spelling (PUEBI).

During the learning process which is still one-way, the students only performed as a good listener without any feedback were given by the lecturers. In addition, with the condition of college students while working make the learning process becomes worse. When the lecture begins the students have been bored, sleepy, tired because they had worked all day and finally still have to fight for college at night. Finally the learning process does not take place optimally so that student learning outcomes are not good in accordance with passing standards set by the university.

In the use of learning media was still dominated in the use of e-learning as a form of facilities provided by the university. The use of e-learning has not been optimally utilized by students. The material presented from one to sixteen meetings still focus on one source of reference, so that students insights and knowledge have not developed yet. If the utilization of interactive mediabased learning media has been applied and developed optimally, it can improve the students learning achievement, especially during Indonesian lecturing at university.

Based on the observation, it found the some problems during the lecturing process in Indonesian language as follows. (1) Student reading culture is still very low. This is evident from the empowerment of reading e-learning activities that have not been optimal. (2) Students difficulties in developing their ideas and the ideas into systematic writing. (3) The method used has not been varied and has not been adjusted with the material and the needs of the students. Therefore, the Quantum Learning method is required to create effective ways to increase student participation, motivation and interest in learning as well as improve the sense of togetherness, improve memory and improve the refinement of behavior. (4) The media used during the learning process has not been referring to interactive media.

Relevant with the problems raised, it is necessary for fixing learning process byapplied the method of Quantum Learning during the lecturing of Indonesian language at the University of Putera Batam. The superiority of Quantum Learning method, those were seen from various learning theories and the implementation were expressed by Sanjaya (2010:3) as follows. (1) Quantum learning stems from cognitive psychology. (2) Quantum learning is more humanistic but not positivistic-empirical, "human-istis", and or nativistic. (3) Quantum learning is more constructivistics but not positivistic-empirical, behavioristic. (4) Quantum learning focuses on meaningful, meaningful interactions but not just transactions of meaning. (5) Quantum learning places great emphasis on accelerating learning with a high degree of success. (6) Quantum learning is crucial to the nature and 
reasonableness of the learning process rather than to artificiality or artificial circumstances. (7) Quantum learning greatly emphasizes the meaningfulness and sincerity of the learning process. (8) Quantum learning has a model that combines context and learning content. (9) Quantum learning focuses on the establishment of academic skills, life skills and physical or material achievement. (10) Quantum learning places values and beliefs as an important part of the learning process. (11) Quantum learning puts diversity and order. (12) Quantum learning integrates the totality of body and mind in the learning process.

Relevant with the research that had ever been conducted by Oktavia ( 2017)can be concluded that the method of quantum learning affected the students positively. First, the score of student test results that was taught by the quantum learning method supported by the technology based learning media was higher than the students taught used conventional method. Second, there was an interaction between the method of quantum learning aided by technology-based learning media in student achievement grade XII SMA Negeri 5 Batam.

Quantum learning changes the learning process with great nuance, including all the links, interactions and differences that maximize learning moment and focused on dynamic relationships within the classroom environment (Wena, 2009). Quantum Learning is a new way of integrating learningwhich combines elements of art and targeted achievement for all subjects.

In conducting research that supported the implementation of tri darma perguruan tinggi, then this research has the following benefits. (1) During the research process, the research was able to improve the lecturing process which affected the students learning outcomes in Indonesian general lecturing. (2) The result of the research is able to describe solution and alternative to other lecturers in applying method and media to support lecturing process effectively and comprehensively so that lecturing is enjoyable. (3) The research can be used as an additional reference material for the advanced researchers who have method and research design which are almost the same with researchers conducted in the form of journal publication and national proceeding. (4) The results of theresearch contributes in improving and developing the quality of lecturers as well as in the academic field. (5) The research is for the research team itself as a chance in self-development and continue to strive in improving the quality of further research.

Based on the description, this research is important to do in order to motivate and improve students learning outcomes in the lecturing of Indonesian language. The application of Quantum Learning method is expected to improve the process and learning achievement of Indonesian language as general course at Putera Batam University according to the demands in the applicable curriculum.

\section{METHOD}

This research wasqualiatative research type used descriptive analysis method. Theresearch aimed to describe the used of Quantum Learning methods in Indonesian language courses. Research instruments used to collect research data were observation sheets, field noted and questionnaire. All instrument results will be done by the valid data analysis techniques. The subject of this research were the students of English literature study program in second semester of academic year 2016/2017 Putera Batam University.

\section{FINDING AND DISCUSSION}

This research activity was conducted during the semester of the academic year 2016/2017. The research began on 28 March to July 28, 2017. The process of conducting the research was begun by giving the test to the students. This test was performed to see the students early skills about language, diction, effective sentences, paragraphs, scientific essays and the application of Indonesian Spelling (EBI). The instruments are used as follows. First, the field notes. Field notes in the form of recording research that occurred in the field during the research that took place. Second, interview forms. This interview forms was used to collect information, data or opinions through individual questions and answeredthem which were asked to the lecturers and students. Third, the questionnaire. Questionnaire was used to know the perception and the students response about the application of Quantum learning method to the lecturing process of Indonesian language. This was important because students were the most interested subjects to evaluate or respond to the strengths and weaknesses of the teaching methods used by lecturers. Questionnaires were completed by students after the cycle. In addition, it is also used to observe students level ability and enthusiasm in learning. Observations are conducted by observers (collaborators).

In filling in the questionnaire, students fill objectively according to their experiences and feelings. Students were also prohibited discussion in filling the questionnaire. Before the questionnaire distributed, the questionnaire was also validated for validating data. The valid questionnaire items were consists of 25 statement items.

Relevant with the conclusion of the research (Sari, Intan Kumala, Budhi Setiawan, 2012) The application of Quantum Learning method with clustering technique can improve the quality of writing poetry process. This was seen in the sincerity, spirite and enthusiasm of the students when given the task of creating the clustering framework techniques and decorating poetry in the learning process. Procedure of application of Quantum Learning method with clustering technique that could improve the student activeness during students perception, interest and motivation during learning activity and to increase students activity and activeness when lecturers delivered material. In the first cycle students who looked active during apperception as much as 68\%, increased to $88 \%$ in the second cycle. In the first cycle, the interest and motivation of students when following the learning 
activities as much as $63 \%$, increased to $80 \%$ in the second cycle. In the first cycle, the students attention when the lecturer delivered the material as much as $60 \%$, increased to $75 \%$ in the second cycle.

Students were given the treatment of Quantum Learning method during the learning process. The following (DePorter, Bobbi Reardon, Mark, Nouri, 2010) develops strategies or steps for designing quantum learning known as "Transplanting", namely (1) Grow, cultivate interest satisfactorily "What Is the Benefit for Me" (Quiet), and the benefit for student life; (2) Natural, creating or generating common experiences that all students can understand; (3) Name, provide keywords, concepts, formulas, strategies: an "input" (4) Demonstrate, provide opportunities for learners to show that they "know"; (5) Repeat, showing students ways of repeating the material and affirming, "I know that I do know this" and (6) Celebrating recognition for the completion, participation, and acquisition of skills and knowledge. Form of celebration can be a compliment, give a gift, sing together applause with various variations and et cetera.

Based on the results of observation sheet analysis, during the learning process using Quantum Learning method showed a significant influence. It showed that students from week to week were no longer being late. Students also showed the active attitude for each lecturing process conducting. In addition, students were able to give solutions and answer the questions' friends in class. This means that the advantages of Quantum Learning method in accordance with the reality that held during the study took place.

In principle, the Quantum Learning method has an impact on student learning outcomes. This was due to the advantages possessed by the strategy of Quantum Learning method. This method was able to show its superiority during Indonesian lecturing. Coupled with the utilization of e-learning was able to stimulate interest and motivation the students learning because the interactive media made students were not monotonous. Using the media-based Quantum Learning method aimed to facilitate students in developing thoughts, ideas and consept in learning Indonesian. The used of interactive media was expected to improve the process and learning outcomes of Indonesian students.

By using the method of Quantum Learning could answer some problems and provide the solutions in learning Indonesian for students of English Literature program in Putera Batam University. Problems in learning Indonesian language among students practicingwasstill low in reading. By using innovative methods was able to fire the spirit and students willingness to read. This was indicated before the lecturing begun, the students had read the basic material books that would be discussed each time in every meeting. From the first week there were still a few students who did reading activities. However, from week to week showed a significant increased. This was also shown from the results of tests and students exercises who have increased.

By applying the interactive media-based Quantum Learning method, students who initially had difficulties in developing their ideas and thought into written form systematically had been able to find a solution. Students had gradually been able to write their ideas systematically and in accordance with the rules of scientific writing. Starting from the proper use of diction, easy to understand sentences, paragraf arrangement and the used of Indonesian Spelling (EBI) in accordance with existing guidelines. Therefore, the Quantum Learning method was able to create effective ways to increase student participation, motivation and interest in learning as well as enhance a sense of togetherness, improve memory and improve the refinement of behavior.

Substance behavior was meant because the language can not be separated from culture. With the existence of culture created by society able to form the students character. Students were not only demanded for potential excellence, but also on the formation of students characters intelligent in the attitude and speech. Throught the implementation of the method of Quantum Learning based on interactive media, it made the students superior and had good character in campus environment, work environment, and society environment. From every time, the meeting, the student has shown the subtlety of behavior that was demanded in the principle of Quantum Learning method.

Quantum Learning method aimed to create an effective learning environment, design curriculum, deliver content and facilitate the learning process. Quantum Learning created effective ways to increase students participation, motivation and interest in learning, enhanced a sense of community, improved memory and improves the refinement of behavior (DePorter, Bobbi Reardon, Mark Nouri, 2010).

The Quantum Learning method in Indonesian lecturing aimed to create an effective learning environment, designed curriculum, delivered content and facilitated the learning process. The Quantum Learning method created effective ways to increase student participation, motivation and interest in learning, enhanced a sense of community, improved memory and enhanced the refinement of behavior. The Quantum Learning method enabled the acceleration of learning by removing natural learning barriers by using music which engaged the involvement students activeness. The Quantum Learning method did not assume students who fail but only students who had not found the right way to learn. Therefore, the lecturers facilitated and changed the learning environment.

The impact of this research motivated and influenced student achievement to be better in learning Indonesian language. The application of Quantum Learning method expected to improve the process and improved the learning students achievement in Indonesian language as general course in Putera Batam University according to the demands in the applicable curriculum. Through technology-based learning media, students understood themselves about Indonesian material well. In previous research, no other researchers conducted a study on the influence of Quantum Learning method on student achievement in Indonesian language as general course at Putera Batam University. Learning materials were in the form of language, diction, effective sentences, paragraphs, scientific essay and application of Indonesian Spelling (EBI). 


\section{CONCLUSION AND RECOMMENDATION}

The results of this research indicated that the Quantum Learning method gave a positive impact during the lecturing process of Indonesian language. This was evident in the interest of reading students who were getting high and good learning motivation. With the existence of it supported the students achievement, especially in lecturing of Indonesia language. Indonesian language course was the foundation that became the basic fulfiment for students to write the task and finish the thesis. Learning materials were in the form of language, diction, effective sentences, paragraphs, scientific essay and application of Indonesian Spelling (EBI).

Based on the results data analyzing, it suggested that this research could be used as an additional reference in designing and using methods and instructional media applied by lecturers to improve the students motivation during the lecturing. During the research process using the Quantum Learning method so that it could support students learning outcomes. This Quantum Learning method could focus with the students attention on quality and meaningful interaction during lecturing process in learning Indonesian language.

\section{CONCLUSION}

The implementation of a collaborative reading strategy in learning to understand literature has significantly increased student engagement. Involvement in their learning increases with the identification of some behaviors prominently during the learning process, such as responding to tasks spontaneously, being active in discussions, being able to work together, taking responsibility, being serious / enthusiastic in lecturing, and completing tasks on time. Tasks and lecture activities that are packaged in the collaborative reading strategies implemented have been able to make students understand the reading with the steps that are systematic and directed, as written through the diary. The student's positive response is mainly because the learning takes place fun / exciting and gives new insights as revealed through daily diaries and interview results.

Increased student activity after the implementation of collaborative reading strategies is also followed by increased ability to understand their reading. The results obtained can be concluded that the two indicators seen in this study all the results increased starting from pre cycle, first cycle, and the second cycle. For the first indicator that is an understanding on the evaluative level of value on pre cycle 47.8 and increased to 60.3 in the first cycle, eventually became 71.8 in the second cycle. In this case increased by $24 \%$. For the second indicator that is understanding on the appreciative level of value acquisition on pre treatment 41.9 up to 53,4 in the first cycle and up again to 66 in second cycle. This indicator experienced an increase of $24.1 \%$.

Based on the research conclusions can be interpreted that the learning process and student learning outcomes in understanding the reading can be increased through the use of collaborative reading strategy. In other words, the application of collaborative reading strategies is effective enough to improve reading comprehension.

\section{References}

DePorter, Bobbi. Reardon, Mark. Nouri, S. S. (2010). Quantum Teaching: mempraktekan Quantum Teaching di ruang-ruang Kelas. Bandung: Kaifa.

Oktavia, Y. (2017). The Effectiveness of Quantum Learning Method Technology- Based Assisted Learning Media Toward Students ' Learning Achievement on Indonesian Subject at Grade XII of SMAN 5 Batam. In ICST 2016 (Vol. 1).

Sari, Intan Kumala, Budhi Setiawan, K. S. (2012). Penerapan metode quantum learning dengan teknik pengelompokan (clustering) untuk meningkatkan kemampuan menulis puisi pada siswa sekolah dasar.BASASTRA Jurnal Penelitian Bahasa, Sastra Indonesia Dan Pengajarannya, 1 nomor 3 , 30-42.

Wena, M. (2009). Strategi Pembelajaran Inovatif Kontemporer. Suatu Tinjauan Konseptual Operasional. Jakarta: Bumi Aksara. 